\section{On copyright \\ Copyright in a networked world: permissions services}

Michael Seadle
What happens when "fair use", "fair dealing", face-to-face teaching guidelines and other copyright exceptions do not apply? Only three choices remain:

(1) give up plans to use the protected work;

(2) make a risk-assessment about the likelihood of a lawsuit; or

(3) seek a permission from the rights holder.

This column examines both public and internal library-based permissions services.

\section{Public permissions services}

Before the Michigan Document Services case (Princeton University Press v. Michigan Document

\section{The author}

Michael Seadle is Editor of Library Hi Tech. He is also Copyright Librarian and Head of the Digital and Multimedia Center at Michigan State University.

\section{Keywords}

Copyright, Libraries, Teaching

\section{Abstract}

What happens when "fair use", "fair dealing", face-to-face teaching guidelines and other copyright exceptions do not apply? Only three choices remain: give up plans to use the protected work, make a risk-assessment about the likelihood of a lawsuit, or seek a permission from the rights holder. This column examines both public and internal library-based permissions services.

\section{Electronic access}

The research register for this journal is available at http://www.emeraldinsight.com/researchregisters

The current issue and full text archive of this journal is available at

http://www.emeraldinsight.com/0737-8831.htm

Library Hi Tech

Volume $20 \cdot$ Number $4 \cdot 2002 \cdot$ pp. 472-476

(C) MCB UP Limited · ISSN 0737-8831

DOI $10.1108 / 07378830210452686$
Services, 1996), many US course-pack

producers hoped that some form of educational fair use would protect them from lawsuits for infringement. Today such copy services generally have staff who contact publishers either directly, or more often via public permissions services.

These services tend to deal only with works created in their own country because of the lingering national character of copyright law. The exemptions for educational and research uses vary widely, as do the mechanisms for fee collection.

\section{US services}

The US-based Copyright Clearance Center (CCC) [1] has agreements with most of the standard US commercial and academic publishers. These agreements set forth the rate structure and any restrictions on paper copies of each work by those publishers. This serves the needs of course pack producers well, since they can pass the cost along to buyers.

The CCC also handles digital permissions through its Electronic Course Content Service. Some publishers have pre-authorized permissions through CCC, and have established a rate structure so that the cost can be established with a single search. The CCC adds a service charge of $\$ 0.015$ per page and per student. For a ten-page article for a class of 30 , this would add up to $\$ 4.50$ in service charges, plus whatever royalty the publisher

The author is not a lawyer, and nothing in this column should be considered legal advice. 
(rights owner) charged. There is a minimum of $\$ 2.50$ per item, and a maximum of $\$ 6.50$. The time saving is significant, and easily recoups the service cost. At this point the service is available only to US customers.

It is important to remember that the CCC's database is not comprehensive. In four random searches by authors whose works had major commercial publishers, only one turned up in the Academic Permissions Service search. The searches were done using both ISBN

(International Standard Book Number) and an exact title that was cut and pasted from the Michigan State University (MSU) online catalog. One book was on history (Oxford University Press, 1999), one on computing (McGraw Hill, 1991), two on engineering (Prentice Hall, 1999; IEEE Press, 2000). The one that turned up was in fact the earlier edition of the IEEE publication, which MacMillan had published in 1993. This sounds discouraging, but the CCC does offer to work with publishers and authors to try to get permissions for works not already in their database.

In general the CCC does not have agreements with small or defunct publishers or individual authors. These are areas where their coverage will doubtless grow over time as they receive requests, but the demand is probably both small and irregular. It makes sense for them to focus their resources on the major publishers that most customers want. Nonetheless they are always a good starting point for US materials, and searching their databases takes only minutes.

Although accounts are not necessary to do a search, establishing an account is relatively easy via online forms. An account can either be for an individual or an institution, and each account can have multiple users with separate passwords and ids.

\section{Other English language services}

For non-USA English language material, similar organizations exist:

- Australia: Copyright Agency Ltd (CAL) [2].

- Britain: Authors' Licensing and Collecting Society Ltd (ALCS) [3], The Copyright Licensing Agency Ltd (CLA) [4], International Federation of the Periodical Press (FIPP) [5], Newspaper Licensing Agency (NLA) [6].
- Canada: Canadian Copyright Licensing Agency (CANCOPY) [7], Canadian Publishers Council (CPC) [8], and Société Québecoise de Gestion Collective des Droits de Reproduction (COPIBEC) [9].

- New Zealand: Copyright Licensing Limited (CLL) [10]

The nature of the licenses in these countries varies significantly, depending on whether the law provides for statutory licenses that cover educational (or other) uses. Most services also handle permissions publisher by publisher and title by title.

CLA (Britain) collects revenues from photocopying licenses, which it then distributes to the Publishers' Licensing Society and Author's Licensing and Collecting Society. CLA deals only with books, journals and magazines, not music, maps, or newspapers. It is developing licenses for digital copies on intranets only. At present it appears to have no licenses for public access to digital materials (CLA, 2000, p. 3; 2001, p. 3)

CAL (Australia) provides a statutory license for educational institutions that allows them to make limited numbers of copies of protected works for educational purposes. CAL also handles educational digital copying in digital form through changes in the 1968 Copyright Act that came into force in March 2001 (CAL, 2001).

CANCOPY (Canada) represents " 4,600

Canadian creators and 420 Canadian publishers", and has reciprocal agreements with similar agencies (CANCOPY, 2002). Rather than searching a database, they give email addresses for contacting staff about particular permissions. CANCOPY does assist with digital licenses, but charges a 10 per cent fee on royalties.

CLL (New Zealand) offers licenses for copying beyond the statutory limits for educational use (e.g. 10 per cent or one chapter of a book, or one article from a periodical). The charges are based on full-time student enrollment. The CLL Website makes no comment about digital or electronic licensing.

\section{Non-English language services}

For non-English language material, a few of the relevant organizations include: 
- France: Centre Français d'Exploitation du Droit de Copie (CFC)[11].

- Germany: Deutscher Journalisten-Verband e.V. (DJV) [12], Verwertungsgesellschaft Bild-Kunst (VG Bild-Kunst)[13], Verwertungsgesellschaft WORT (VG WORT) [14].

- Netherlands: Stichting BEELDRECHT[15], Stichting BURAFO[16], Stichting LIRA[17], Stichting Reprorecht (SR) [18].

The CFC (France) is the agency which manages compulsory licensing in France under the law of 3 January 1995. It is the only agency which handles photocopies for books and newspapers, and automatically represents all authors and editors in France. It contracts with the legal entity whose staff or students will make the copies. At present CFC cannot authorize digital copies. Such arrangements must be made with each author or editor (CFC, 2002).

In Germany the Verwertungsgesellschaft WORT takes responsibility for copyright permissions that "individual rights owners could not manage on their own for practical or legal reasons" (Verwertungsgesellschaft WORT, 2002b). At present, it appears to have no permissions for Internet use, but it has just announced a new agreement on royalty payments for CD-ROM burners that parallel the payments build into the cost of photocopying equipment (Verwertungsgesellschaft WORT, 2002b).

SR (Netherlands) handles photocopying licenses for books, magazines, and newspapers, and has special provisions for staff copying in publicly supported libraries. No provision for digital copies is apparent on their Website, which is entirely in Dutch and clearly not designed for foreign use, despite the relatively large number of English-language publications in the Netherlands.

\section{Library-based permissions services}

Few libraries operate an internal permissions service, partly because this is not a traditional library service, partly because of the expense and expertise needed to set one up. Michigan State University Library (MSUL) is an exception. It operates a permissions service whose primary mission is to work with the university's distance education program and several grant projects. It handles only digital permissions. University printing or local copy shops handle course pack and other paper copy requests.

\section{Staffing and resources}

MSUL now has two full-time staff for this service, one an administrative assistant, one clerical. In 1999 one full time person could handle all of the requests, and do some other work, but the volume of requests has grown as the university's distance education offerings have expanded and as new grant projects were funded. Also individual faculty and departments began using the service once they learned about it. Work for them is normally done in the comparatively quieter times after the semester has begun, and when no grant-project deadline looms.

Both of these staff are well educated. One has a masters degree, the other is working on one. They know a great deal about copyright law, but in cases where it is uncertain whether a permission is required for the particular use, they consult me in my role as copyright librarian. This too is a relatively new position which the library established because every form of digital reformatting raises potential copyright issues. The boundaries of this work were drawn carefully to distinguish between providing information about copyright law and intellectual property policy. It does not take full time, but requires constant attention since the law is always changing. Another librarian assists on copyright decisions and training when I am away.

In addition to this level of staffing, the work requires a substantial telephone budget, since the only effective way to get some permissions is to talk to people. Email and faxed requests are easy to ignore, but a pleasant and persuasive phone manner can move requests to the top of the pile for a large publisher or a private rights holder. Foreign calls are common too, and a knowledge of a wide range of languages helps. Although a database maintains records of all the permissions requests, whether granted or not, several large filing cabinets are needed to hold all the paper records. 


\section{Types and problems}

The subject matter of the requests ranges widely, depending on the nature of the new distance education courses being offered and types of grant projects. Many of the distance education courses emphasize technical or practical subjects, with courses ranging from "Administrative skills for social work practice" to "Watershed assessment and tools". Grant projects include digitizing spoken word materials for the multi-million dollar Digital Library Initiative (phase 2)- funded National Gallery of the Spoken Word to the American Orchid Society-funded Digital Orchid Library prototype. In general, though, the subject matter is irrelevant to what makes requests easy or hard.

Three factors determine how difficult it will be get an answer - any answer regardless of whether it is positive or negative - on a permissions request.

First, whether the citation is complete and accurate. While requestors are expected to provide full citations, they often leave gaps or put in erroneous information that forces staff either to reject the request or to research it with the help of the appropriate bibliographer. Inaccurate information is the biggest problem, because it can lead to long false trails before the error is discovered.

Second, whether ownership of the copyright is clear. Often authors transfer their copyright to the publisher, but not always. Some journals have a policy of requiring the copyright, but make exceptions for important authors who will only give a permission to publish. Many authors forget whether they transferred their copyright or not, or do not understand enough about copyright law to know whether they made a legal transfer or now. Under US law, only a signed transfer counts.

Third, whether the work is old or recent. Older works are usually a problem, especially if they were unpublished or if the publisher has ceased to operate under the same name. The rights holders for works published commercially during the last decade or so can usually be found easily through the CCC. Works published in the last half dozen years can be found via publishers' guides. Works published on the Web in the last few years can be found by visiting the Website. Unpublished works from the last year or two can usually be traced back to the author by questioning the requestor.

All other older works present potentially serious challenges. Older unpublished manuscripts require tracking down an author whose address has probably changed more than once, though those with long-standing institutional connections can be traced with patience and persistence. Larger publishers that swallow smaller ones normally acquire their intellectual property, but rarely seem to interfile the records or even to know where they are. Some small publishers even just go out of business completely, perhaps because of the owner's death or ill health. If the records are saved at all, they languish in a relative's basement at best.

Heirs invariably present a challenge, since only the most successful and conscientious authors make any specific provision for any intellectual property that they continue to own. Often heirs have no idea whether they inherited copyrights. Some automatically give permissions to anything without checking. Others automatically deny permissions or request unreasonable fees. A permission from an heir shows good intentions, but offers little guarantee of protection against infringement by the true copyright holder.

\section{Costs}

Public permissions services bill their customers for the royalty payments, and internal services need to do the same. MSUL's service bills the requesting department, grant account, or distance education program using long-standing internal university billing mechanisms. It does not bill students, faculty, or other end-users directly.

Commercial electronic course reserve software often includes billing mechanisms that can charge students by the page, by the article, by the download, or by the time spent. These charge-back mechanisms all have educational consequences for the poor and the frugal, who might be expected to browse or reread less as a result. Establishing an internal permissions service does not necessarily involve a library in these kinds of billing mechanisms. There are alternatives, such as one-time course fees or even higher tuition to spread the costs. In the 
end, however, someone must pay when royalties are requested.

One benefit of an internal permissions service is that it can emphasize the library's non-profit educational mission in requesting free or inexpensive use. This has been surprisingly effective, perhaps because of the university's reputation and strong commitment to public service, perhaps because the staff are both effective and sincere. The savings are not easily quantified, and the approach probably would not work on most large commercial publishers. But it is worth trying. One of the largest and least loved journal publishers in the academic world has occasionally waived royalties for a class.

\section{Conclusion}

The main reason for a library to set up its own internal permissions service is when it must get permissions that the public services cannot provide. Permissions for digital copies in particular still usually need special handling, though the CCC is moving fast to provide service in this area for US materials.

Permissions for digital copies of European materials may well require direct contacts for much longer.

The demand for these permissions services is substantial. One consequence of not providing them appears to be an increased willingness to risk infringement, not from malicious intent, but from simple frustration at the impossibility of finding how and whom to ask.

\section{Notes}

1 www.copyright.com/

2 www.copyright.com.au

3 www.alcs.co.uk/
4 www.cla.co.uk/

5 www.fipp.com/

6 www.nla.co.uk/

7 www.cancopy.com

8 www.pubcouncil.ca/

9 www.copibec.qc.cal

10 www.copyright.co.nz/

11 www.cfcopies.com/

12 www.djv.de/

13 www.bildkunst.de/

14 www.vgwort.de/

15 www.cedar.nl/beeldrecht/

16 www.cedar.nl/burafo

17 www.cedar.nl/LIRA

18 www.cedar.nl/reprorecht

\section{References}

Canadian Copyright Licensing Agency (2002), Benefits of a CANCOPY License, available at: www. cancopy.com/ inside.epl?folder=cube1 $\&$ page $=$ benefits.html (accessed August 2002).

Centre Français d'Exploitation du Droit de Copie (2002), Qu'en Est-il de l'Édition Électronique?, available at: www.cfcopies.com/vous_utilisez/index.htm (accessed August 2002).

Copyright Agency Ltd (2001), Digital Update for Educational Institutions, 20 June, available at: www. copyright.com.au/info\%20sheets/LI26_digital\% 20update\%20for\%20edu\%20inst.pdf (accessed 14 August 2002).

Copyright Licensing Agency (2000), Digitisation and Electronic Copying, available at: www.cla.co.uk/ media/general-digitisation.pdf (accessed 14 August 2002).

Copyright Licensing Agency (2001), What It Is, What It Does, Why It Matters, April, available at: www.cla.co.uk/ what_is_CLA/whatis.pdf (accessed 14 August 2002).

Princeton University Press and St Martin's Press v. Michigan Document Services (1996), 99 F.3d 1381; 1996 US App. LEXIS 29132; 1996 FED App. 0357P (6th Cir.); 40 U.S.P.Q.2D (BNA) 1641.

Verwertungsgesellschaft WORT (2002a), Die VG WORT im Portrait, (my translation), available at: www. vgwort.de/importrait.php (accessed 14 August 2002). Verwertungsgesellschaft WORT (2002b), Einigung über Urhebervergütung für CD-Brenner, 1 August, available at: www.vgwort.de/aktuell.php 